\title{
Effects of Different Land Use Classes on Some Selected Physico-chemical Properties of Soil of District Ganderbal
}

\author{
Khushboo Farooq*, Mohammad Auyoub Bhat, Mushtaq Ahmad Wani, \\ Shabir Ahmed Bangroo and Baseerat Binti Nabi \\ Division of Soil Science, Sher-e-Kashmir University of Agricultural Sciences and Technology \\ of Kashmir, Jammu and Kashmir, India \\ *Corresponding author
}

\section{A B S T R A C T}

The present experiment was conducted to study the effects of different land use classes on some selected physico-chemical properties of soil. Surface $(0-20 \mathrm{~cm})$ and Sub-surface (20$40 \mathrm{~cm})$ soil samples were collected from forest, agriculture and horticulture soils. The processed soil samples were used for laboratory studies i.e. texture, $\mathrm{pH}, \mathrm{EC}$, organic carbon, calcium carbonate and cation exchange capacity. The soils of District Ganderbal under different land use systems showed textural variation i.e., silt loam to silty clay loam in forest and horticulture soils while it showed silty clay loam to clay loam in agricultural soils. The forest, agricultural and horticulture land uses showed a $\mathrm{pH}$ of 6.7, 7.34 and 7.14 and 6.9, 7.34 and 7.34 in surface and sub-surface soils respectively. The EC of surface soils and sub-surface soils ranged between $0.16,0.23$ and $0.21 \mathrm{dSm}^{-1}$ and $0.23,0.25$ and $0.24 \mathrm{dSm}^{-1}$ in forest, agricultural and horticultural soils respectively. The organic carbon content in surface soils and sub-surface varied from 1.80, 1.09 and 1.10 and 1.5, 0.67, 1.00 per cent in forest, agricultural and horticultural soils respectively. The calcium carbonate content in surface soils and sub-surface soils varied from $0.15,0.57$ and 0.61 and 0.19 , 0.67 and 0.66 per cent in forest, agricultural and Horticultural soils respectively. The cation exchange capacity under selected land uses varied from 15.48, 15.64 and 15.11C mol $_{\mathrm{c}} \mathrm{kg}^{-1}$ and in sub-surface soils from $15.99,16.33$ and $16.15 \mathrm{C} \mathrm{mol} \mathrm{ckg}^{-1}$ in forest, agriculture and horticulture respectively.

\section{Introduction}

Soil is key to sustaining life, affecting air and water quality, the growth of plants and crops, and the health of the entire planet. Soil is the dynamic link between the biosphere and lithosphere and constitutes a practically nonrenewable (very low rate of formation) natural resource, with a key role for the environment and for the agriculture (Moraetis et al., 2016). Soil is a complex matter and comprises minerals, soil organic matter, water, and air. These fractions greatly influence soil texture, structure, and porosity. These properties subsequently affect air and water movement in the soil layers, and thus the soil's ability to function. Therefore, soil physicochemical properties have a great 
influence on the soil quality. The physical quality of the soil, which creates suitable environment for the availability and uptake of the plant nutrients, is generally ignored (Rasool et al., 2008). Soil texture especially can have a profound effect on many other properties. Thus, soil texture is considered one of the most important physical properties of soil. The balance between cation and anion uptake by the plant affects the $\mathrm{pH}$ in the rhizosphere. The rhizosphere $\mathrm{pH}$ can change with the form and concentration of fertilizer, and the extent of the $\mathrm{pH}$ change around the root depends on the buffer capacity of the soil. Cation exchange capacity (CEC) of the soil is an important consideration in determining the amount and frequency of cations that need to be by the plant. In most agricultural soils and irrigation water, $\mathrm{Ca}$ and $\mathrm{Mg}$ are present in larger quantities than those taken up by any crop, and their supply is usually satisfied with water mass flow. Soil organic matter (SOM) strongly influences the crop growth and productivity by providing nutrients and modifying soil quality indices such as decreasing soil compaction, stabilizing soil structure due to increased soil aggregation, and controlling soil erosion (Ding et al., 2012). This paper pays attention to the physical and chemical properties of soil due to their importance in plant growth and soil stability.

\section{Materials and Methods}

Surface soil samples $(0-20 \mathrm{~cm})$ and subsurface soil samples $(20-40 \mathrm{~cm})$ were collected from different land uses of district Ganderbal and from each land use a total of five soil samples were collected. The coordinates of the sites were recorded using GPS receiver (Garmin Oregon 650).The soil samples were air dried in shade, grounded with wooden mallet and passed through a $2 \mathrm{~mm}$ sieve. For organic carbon determination, the soil was passed through $0.2 \mathrm{~mm}$ sieve. The processed soil samples were analyzed for physico-chemical and mechanical properties.

The $\mathrm{pH}$ of the soil was measured in 1:2.5 soil water suspension with the help of Digital Glass electrode $\mathrm{pH}$ meter by Jackson (1973). The electrical conductivity of the soil water extract (1:2.5) was read with the help of Conductivity meter by Jackson (1973). Organic carbon was determined by wet oxidation method given by Piper (1996). The mechanical analysis of the soil sample was done by following the International Pipette method as described by Piper (1966). Cation Exchange capacity of the soil was determined according to the procedure outlined by Rhoades (1982). Calcium carbonate was determined by the method given by Puri (1930).

\section{Results and Discussion}

The texture of the soils of district Ganderbal varied from silty loam to silty clay loam (Table 1). Surface soils of forest in the district Ganderbal had predominantly silt texture. Higher concentration of Silt in the surface soils of forests was obviously due to the impact of precipitation, snow melt and temperature on these soils that might have resulted in soil erosion and loss of humus. The results are corroborated by the findings of Yu yang et al., (2017) who also reported higher silt in surface soils of forests.

Depth wise distribution of soil separates in different land uses revealed that the sand content was more noticeable at upper depth while as silt and clay were more concentrated at lower depths. This might be accredited to illuviation and translocation of clay to subsurface layers. These results are in agreement with the findings of Bashir et al., (2016) and Harsha and Jagadeesh (2017). Variation in the particle size distribution in horticulture soils 
might be due to land use pattern as orchards generally contained more fine soil particles (silt and clay) as demonstrated by Yusong et al., (2017). These soils are relatively high in $\mathrm{K}$ due to the dominance of $\mathrm{K}$ bearing and associated minerals in clay and silt fractions. The results are corroborated by the findings of Srinivasarao et al., (2013).
These soils were found to possess medium to moderately fine texture. Similar observations were also reported by Bangroo et al., (2010). Mahapatra et al., (2000) observed that the altitude and relief play a significant role in soil properties while working with Kashmir valley soils.

Table.1 Soil textural classes for different land uses

\begin{tabular}{|c|c|c|c|c|c|c|c|}
\hline Land use & sample & depth & course sand & Sand & Silt & clay & textural class \\
\hline \multirow{10}{*}{ Forest } & S1 & $0-20$ & 1.97 & 24.25 & 50.45 & 22.88 & silt loam \\
\hline & & $20-40$ & 1.81 & 25.64 & 50.98 & 24.37 & silt loam \\
\hline & $\mathrm{S} 2$ & $0-20$ & 2.12 & 22.6 & 48.24 & 24.86 & silt loam \\
\hline & & $20-40$ & 1.82 & 22.95 & 51.48 & 27 & silt loam \\
\hline & S3 & $0-20$ & 1 & 18.32 & 40.2 & 38.4 & silty clay loam \\
\hline & & $20-40$ & 0.99 & 20.83 & 41.83 & 38.35 & silty clay loam \\
\hline & $\mathrm{S} 4$ & $0-20$ & 1.42 & 18.2 & 40.33 & 39.92 & silty clay loam \\
\hline & & $20-40$ & 1.32 & 18.48 & 40.81 & 40.99 & silty clay loam \\
\hline & S5 & $0-20$ & 1.6 & 22.5 & 52.27 & 23.23 & silt loam \\
\hline & & $20-40$ & 1.54 & 22.9 & 52.95 & 23.81 & silt loam \\
\hline \multirow{10}{*}{ Agriculture } & S6 & $0-20$ & 0.9 & 39.1 & 27.8 & 32.2 & clay loam \\
\hline & & $20-40$ & 1.4 & 40.47 & 28.7 & 32.43 & clay loam \\
\hline & S7 & $0-20$ & 1.1 & 37.24 & 40.23 & 19.67 & loamy \\
\hline & & $20-40$ & 1.04 & 38.94 & 41.43 & 23.59 & loamy \\
\hline & S8 & $0-20$ & 0.92 & 26.18 & 48.69 & 22.61 & clay loam \\
\hline & & $20-40$ & 0.9 & 26.56 & 50.33 & 24.41 & clay loam \\
\hline & S9 & $0-20$ & 1 & 37.9 & 27.7 & 32.4 & clay loam \\
\hline & & $20-40$ & 0.99 & 39.19 & 29.7 & 33.12 & clay loam \\
\hline & S10 & $0-20$ & 2 & 43.12 & 32.13 & 21.45 & loamy \\
\hline & & $20-40$ & 1.99 & 43.84 & 32.99 & 21.42 & loamy \\
\hline \multirow{10}{*}{ Horticulture } & S11 & $0-20$ & 1.34 & 34.58 & 38.21 & 25.89 & loamy \\
\hline & & $20-40$ & 0.99 & 35.12 & 40.8 & 26.09 & loamy \\
\hline & S12 & $0-20$ & 1.93 & 24.51 & 49.8 & 22.76 & silt loam \\
\hline & & $20-40$ & 1.48 & 25.82 & 51.04 & 24.66 & silt loam \\
\hline & S13 & $0-20$ & 1.79 & 23.94 & 52.23 & 22.04 & silt loam \\
\hline & & $20-40$ & 1.6 & 24.8 & 54.2 & 22.4 & silt loam \\
\hline & S14 & $0-20$ & 1.04 & 38.49 & 29.02 & 31.45 & clay loam \\
\hline & & $20-40$ & 1.03 & 39.32 & 30.8 & 32.85 & clay loam \\
\hline & S15 & $0-20$ & 1 & 38.1 & 27.7 & 31.2 & clay loam \\
\hline & & $20-40$ & 0.99 & 39.23 & 29.7 & 33.08 & clay loam \\
\hline
\end{tabular}


Table.2 Physico-chemical properties of soils of District Ganderbal under land uses

\begin{tabular}{|c|c|c|c|c|c|c|c|}
\hline Land use & sample & depth & pH & $\begin{array}{c}\mathrm{EC} \\
(\mathrm{dSm}-1)\end{array}$ & $\begin{array}{c}\text { OC } \\
(\%)\end{array}$ & $\begin{array}{c}\mathrm{CaCo3} \\
(\%)\end{array}$ & CEC \\
\hline \multirow{10}{*}{ Forest } & $\mathrm{S} 1$ & $0-20$ & 7.24 & 0.15 & 1.86 & 0.85 & 17.4 \\
\hline & & $20-40$ & 7.17 & 0.17 & 1.5 & 0.97 & 17.8 \\
\hline & S2 & $0-20$ & 8.29 & 0.12 & 1.26 & 1.18 & 16.98 \\
\hline & & $20-40$ & 8.17 & 0.14 & 1.09 & 1.49 & 17.85 \\
\hline & S3 & $0-20$ & 6.81 & 0.15 & 2.01 & 1.05 & 17.82 \\
\hline & & $20-40$ & 7.2 & 0.17 & 1.96 & 1.58 & 18.1 \\
\hline & S4 & $0-20$ & 7.56 & 0.1 & 1.98 & 0.88 & 17.1 \\
\hline & & $20-40$ & 7.3 & 0.12 & 1.86 & 0.9 & 17.9 \\
\hline & S5 & $0-20$ & 7.82 & 0.09 & 1.9 & 0.79 & 16.8 \\
\hline & & $20-40$ & 7.55 & 0.1 & 1.5 & 0.92 & 17.32 \\
\hline \multirow{10}{*}{ Agriculture } & S6 & $0-20$ & 7.41 & 0.23 & 0.63 & 0.4 & 15.5 \\
\hline & & $20-40$ & 7.38 & 0.25 & 0.79 & 0.52 & 15.8 \\
\hline & S7 & $0-20$ & 7.79 & 0.25 & 0.8 & 0.16 & 15.85 \\
\hline & & $20-40$ & 7.27 & 0.26 & 0.54 & 0.19 & 16.68 \\
\hline & S8 & $0-20$ & 7.26 & 0.28 & 0.76 & 0.17 & 16.23 \\
\hline & & $20-40$ & 7.03 & 0.29 & 0.52 & 0.18 & 16.8 \\
\hline & S9 & $0-20$ & 5.92 & 0.24 & 0.76 & 0.16 & 15.43 \\
\hline & & $20-40$ & 6.54 & 0.25 & 0.52 & 0.2 & 15.65 \\
\hline & S10 & $0-20$ & 8.83 & 0.21 & 0.63 & 0.19 & 16 \\
\hline & & $20-40$ & 8.19 & 0.22 & 0.52 & 0.22 & 16.52 \\
\hline \multirow{10}{*}{ Horticulture } & S11 & $0-20$ & 7 & 0.15 & 1.14 & 0.16 & 13.47 \\
\hline & & $20-40$ & 7.14 & 0.18 & 1.08 & 0.17 & 14.26 \\
\hline & S12 & $0-20$ & 7.13 & 0.25 & 1.16 & 0.18 & 13.2 \\
\hline & & $20-40$ & 7.24 & 0.27 & 1 & 0.2 & 14.83 \\
\hline & S13 & $0-20$ & 6.6 & 0.21 & 1.27 & 0.2 & 14.38 \\
\hline & & $20-40$ & 6.63 & 0.23 & 1.18 & 0.22 & 14.88 \\
\hline & S14 & $0-20$ & 7.2 & 0.25 & 1.07 & 0.21 & 14.36 \\
\hline & & $20-40$ & 7.28 & 0.28 & 0.98 & 0.24 & 14.82 \\
\hline & S15 & $0-20$ & 7.36 & 0.22 & 0.88 & 0.22 & 13.18 \\
\hline & & $20-40$ & 7.45 & 0.24 & 0.59 & 0.24 & 13.96 \\
\hline
\end{tabular}

\section{Soil reaction}

The $\mathrm{pH}$ in the surface soils ranged from 6.17 to 7.30 in forest, 6.97 to 7.67 in Agriculture and 6.63 to 7.45 in Horticultural soils with mean value of $6.7,7.34$ and 7.14 respectively. Whereas in surface soils, the $\mathrm{pH}$ varied from 6.59 to $7.56,6.97$ to 7.67 and 7.14 to 7.63 with a mean value of $6.9,7.34$ to 7.34 in
Forest, Agricultural and Horticultural soils respectively (Table 2 ). The soils were slightly acidic to neutral in reaction which may be due to high rainfall which results in leaching of salts from upper layers and higher organic matter content, which reduces $\mathrm{pH}$ by releasing organic acids. Excess leaching of bases from the soil profile due to heavy rainfall might be caused acidity in these soils (Sharma and 
Singh, 2002). The variation may also be attributed to the amount of clay and organic matter in the soil. These results are in agreement with the findings of Bashir et al., (2016).

\section{Electrical conductivity $\left(\mathrm{dSm}^{-1}\right)$}

Soil electrical conductivity (EC) is a measure of the amount of salts in soil. It is an excellent indicator of nutrient availability and loss, soil texture, and available water capacity. It affects crop yields, the suitability of the soil for certain crops, the amount of water and nutrients available for plant use, and the activity of soil micro-organisms, which influences key soil processes such as the emission of greenhouse gases, including nitrogen oxides, methane, and carbon dioxide.

Excessive salts hinder plant growth by affecting the soil and water balance. The results of the present study revealed a variation in the EC of surface soils and averaged between $0.16,0.23$ and $0.21 \mathrm{dSm}^{-1}$ in forest, agricultural and horticultural soils respectively. Similarly sub-surface soils also exhibited a variation in $\mathrm{EC}$ with mean values of $0.23,0.25$ and $0.24 \mathrm{dSm}^{-1}$ in Forest, Agricultural and Horticultural soils respectively (Table 2). However, The electrical conductivity was within the normal range across different land use systems as value were less than $1 \mathrm{dSm}^{-1}$ and do not impact most crops and soil microbial processes.

The low electrical conductivity may be due to leaching of soluble salts to sub surface layers resulting from heavy precipitation in soils. The differences in electrical conductivity under different land uses may be attributed to soil management practices and altitudinal variation. These results are in conformity with the results of Parihar et al., (2013).

\section{Organic carbon $(\%)$}

The organic carbon content in surface soils varied from 1.26 to 2.01 per cent with a mean value of 1.80 per cent in forest, 0.76 to 1.63 per cent with a mean value of 1.09 in agricultural soils and 0.88 to 1.27 per cent with a mean value of 1.10 in horticultural soils (Table 2). Organic matter in the soils had a faster rate of $\mathrm{K}$ adsorption. This is attributed to the presence of more accessible exchange sites of soil organic matter for K. While as in sub-surface soils, the organic carbon content varied from 1.09 to 1.96 per cent with a mean value of 1.5 per cent in forest, 0.52 to 0.82 per cent with a mean value of 0.67 per cent in agricultural and 0.79 to 1.18 per cent with a mean value of 1.00 per cent in horticultural soils (Table 2). The higher amount of organic carbon in high altitudes may be due to plant biomass, litter quality and climatic factors like temperature, precipitation etc. Because of low temperatures at high altitudes are likely to limit decomposition and other soil processes, researchers have proposed that soil organic carbon (C) concentration may increase while as low values in lower altitudes owe to rapid mineralization and loss of carbon from soils (Sundqvist et al., 2013). These results are in conformity with the findings of Pal et al., (2013). Depth wise analysis for organic carbon showed a decreasing trend owing to the addition of plant residues to the surface layers. These results are in accordance with the findings of Karwade et al., (2020).

\section{Calcium carbonate}

The data presented in table 2 revealed that the calcium carbonate content in surface soils under different land uses varied from 0.05 to 0.22 per cent with a mean value 0.15 per cent in forest, 0.40 to 0.69 per cent with a value of 0.57 per cent in agricultural and 0.56 to 0.68 per cent with a mean value of 0.61 in horticultural soils. While the calcium 
carbonate content in sub-surface soils varied from 0.08 to 0.26 per cent with a mean value of 0.19 per cent in forest, 0.52 to 0.78 per cent with a mean value of 0.67 per cent in agricultural soils and 0.62 to 0.70 per cent with a mean value of 0.66 per cent in horticultural soils.

A consistent increase in calcium carbonate content was observed with increase in depth of soils which might be accredited to the leaching down of calcium carbonate from upper soils surfaces. The results are in conformity with the finding of Karwade et al., (2020) who also found low calcium carbonate in surface layers while working on soils of Himachal Pradesh and Kashmir, respectively.

\section{Cation Exchange Capacity (CEC)}

The results presented in table 2 revealed that the cation exchange capacity under selected land uses varied from 14.28 to $16.10 \mathrm{C}$ mol $_{c}$ $\mathrm{kg}^{-1}$ in Forest, 13.43 to $16.70 \mathrm{C} \mathrm{mol}_{\mathrm{c}} \mathrm{kg}^{-1}$ in Agricultural, 14.47 to $15.38 \mathrm{C} \mathrm{mol}_{\mathrm{c}} \mathrm{kg}^{-1}$ in horticultural soils with a mean value of 15.48 , 15.64 and $15.11 \mathrm{C} \mathrm{mol}_{\mathrm{c}} \mathrm{kg}^{-1}$ respectively. Where as in sub-surface soils it varied from 14.85 to $16.90 \mathrm{C} \mathrm{mol}_{\mathrm{c}} \mathrm{kg}^{-1}$ in forest, 14.65 to $17.52 \mathrm{C} \mathrm{mol}_{\mathrm{c}} \mathrm{kg}^{-1}$ in agricultural and 26 to $16.99 \mathrm{C}$ mol $_{\mathrm{C}} \mathrm{kg}^{-1}$ in horticultural soils with a mean value of $15.99,16.33$ and $16.15 \mathrm{C}$ $\mathrm{mol}_{\mathrm{c}} \mathrm{kg}^{-1}$ respectively. The higher content of cation exchange capacity can be ascribed to higher organic matter content and clay. Wani et al., (2010) also reported a higher range of cation exchange capacity in soils attributed to their corresponding high content of organic matter and clay. Depth wise analysis of these soils for cation exchange capacity showed an increasing trend owing to the variation in organic carbon and clay content in the subsurface soils. This is further in agreement with the findings of Takele et al., (2014).

In conclusion, $\mathrm{pH}$ was almost neutral to slightly acidic in all land uses. Organic carbon and was high in Forest followed by horticultural soils and the agricultural soils. EC, Calcium carbonate was high in agriculture and horticultural soils as compared to forest soils. CEC was almost same in all land uses. Most of the parameters are quite higher or lower than acceptable limits. From the study it is concluded that further study should be carried out about the mineralogical composition of the clays to better understand the quality of soil by different parameters.

\section{References}

Bangroo, S. A. 2010. Potassium releasing and fixing capacity of rainfed maize growing soils of district ganderbal. Thesis. Shere-e-kashmir university of agricultural science and technologyKashmir.

Bashir, U., Ali, T. and Qureshi F. 2016. Distribution of different forms of potassium under temperate conditions of Kashmir. International Journal of Agricultural, Environment and Biotechnology. 9(2): 213-219.

Ding, X., Han, X., Liang, Y., Qiao, Y., Li, L and Li, N.2012. Changes in soil organic carbon pools after 10 years of continuous manuring combined with chemical fertilizer in a Mollisol in China. Soil Tillage Res. 122:36-41.

Harsha, B.R. and Jagadeesh, B.R. 2017. Forms and distribution of potassium in selected maize growing soils of Haveri district of Karnataka, India. International Journal of Current Microbiology and Applied Sciences 6(9): 923-936

Karwade, S., Badole, W.P., Swati, T. and Patel, B. 2020. Distribution of different forms of soil potassium in surface and sub-surface layers of paddy growing areas of Nagpur District. Journal of Pharmocognosy and Phytochemistry. 9(2): 909-915.

Mahapatra, S.K., walia, C.S., Sidhu, G.S., 
Rana, K.P.C. and Tarsem Lal. 2000. Characterization and Classification of the soils of different physiographic units in the sub-humid eco-system of Kashmir region. Journal of Indian society of soil science. 48: 572-577.

Moraetis,D., Simantiris, N.L., Pentari, D., Manoutsoglou, E., Apostolaki, C. and Perdikatsis, V. 2016. Chemical and Physical Characteristics in Uncultivated Soils with Different Lithology in Semiarid Mediterranean Clima. Applied and environmental soil science. Article ID 3590548, http://dx.doi.org/10.1155/2016/359054 8.

Pal, S., Panwar, P. and Bhardwaj, D. R. 2013. Soil quality under forest compared to other land-uses in acid soil of north western Himalaya, India. Annual Forest Research. 56(1): 187-198.

Parihar, P., Singh, V., Bhadauria, U.P.S. 2013. Status of micronutrients in guava orchard soils and plants of Kymore plateau and Satpura hills of Madhya Pradesh. J Indian Soc. Soil Sci.; 61(1):44-46.

Sharma, U.C. and singh, R.P. 2002. Acid soils of india. Their distribution, management and future strategies for higher productivity. Fertilizer news. 47: 45-52.

Srinivasarao, C., Kundu, S., Ramachandrappa, B.K. Sharanbhoopal, R., Lal, R., venkateswarlu, B., Sharawat, L. and Naik, P. 2013. Potassium release characteristics, potassium balance and finger milet (Eleusine coracana G.) yield sustainability in a 27 year long experiment on an Alfisol in the semi arid tropical India. Plant And soil. 13: 1877-1894.

Sundqvist M. K., Sanders N. J. and Wardle D. A. 2013. Community and Ecosystem Responses to Elevational Gradients: Processes, Mechanisms, and Insights for Global Change. Annual Review of Ecology, Evolution and Systematics. 44, 261-280.

Takele, L., Chimdi, A. and Abebaw, A. 2014. Dynamics of soil fertility as influenced by different land use systems and soil depth in west Showa zone, Gindeberet district, Ethiopia. Agriculture, Forestry and Fisheries 3(6): 489-487.

Wani, M. A., Mushtaq, Z. and Nazir, S. 2010. Mapping of micronutrients of the submerged rice soils of Kashmir. Research Journal of Agricultural Sciences, 1: 458-462.

Yusong, D., Chongfa, C., Xia, D., Shuwen, D. and Chen, J. 2017. Fractal feature of soil particle size distribution under different land use patterns in the alluvial fans of collapsing gullies in the hilly granitic region of south china. PLoS ONE 12(3):1-21.

Yuyang, W. and Ouyang, W. 2017. Snowmelt water drives higher soil erosion than rainfall water in a mid-high latitude upland watershed. Journal of Hydrology. 556: 438-448.

\section{How to cite this article:}

Khushboo Farooq, Mohammad Auyoub Bhat, Mushtaq Ahmad Wani, Shabir Ahmed Bangroo and Baseerat Binti Nabi. 2021. Effects of Different Land Use Classes on Some Selected Physico-chemical Properties of Soil of District Ganderbal. Int.J.Curr.Microbiol.App.Sci. 10(01): 200-206. doi: https://doi.org/10.20546/ijcmas.2021.1001.024 